\title{
Some Mixed Evidence of Economic Transformation from Greece: Workforce Patterns and Shifts during the Recession (2008-2013)
}

\author{
Prodromos Prodromidis \\ Centre for Planning \& Economic Research (KEPE), Greece \\ Department of Economics, Athens University of Economics \& Business, Greece
}

Copyright $(\mathcal{C} 2015$ by authors, all rights reserved. Authors agree that this article remains permanently open access under the terms of the Creative Commons Attribution License 4.0 International License

\begin{abstract}
The paper analyzes the quarterly Greek Labor Force Survey estimates from early 2008 to early and mid2013 via linear econometric regressions with robust standard errors. By isolating the seasonal effects it: (a) examines sectoral employment, unemployment and non-participation trend and cyclical aspects across demographic groups at the sub-regional level, as well as regional workforce aspects at the sub-sectoral level, and (b) identifies sub-sectors, places, and segments of the population which diverge from the rest by exhibiting statistically significant reversals in the recessionary pattern. The findings provide (i) interesting insights into the diverse reactions that take place in the Greek workforce amid the recession, as well as (ii) avenues for further research to advance understanding of the underlying causes of these responses and the operation of country's constituent economies.
\end{abstract}

Keywords Job Creation and Destruction, Sectoral Trends, Demographic Groups, Regional Heterogeneity

\section{Introduction}

The purpose of the article is to describe how employment figures evolved across economic sectors and subsectors in Greece, and how demographic groups shifted between workforce participation and abstention at the regional and subregional level in the recent recession.

The recession itself is by and large traced to the spreading in the EU by mid-2008, of the financial crisis that had broken out a few months earlier in the USA. The crisis appears to have been dealt in the EU with a reduction in the money supply (M1), and other moves which, in turn, lead to a deeper contraction of economic activity and slower recovery across the Eurozone $[1,2]$. Its advent in Greece during the third quarter of 2008, exacerbated the country's chronic economic imbalances and, in the absence of a strong production base and viable alternatives to adopting austerity measures, affected a severe downturn, esp. from the signing of the memorandum of understanding (MOU) with the European Commission (EC), European Central Bank (ECB) and the International Monetary Fund (IMF) in May 2010 up to mid-2013, involving successive GDP losses of over $4 \%$ (often 6-8\%) against the same quarter of the preceding year $[3,4]$. At the same time, the unemployment rate in the Eurozone rose from slightly below 7\% (in early 2008) to about $12 \%$ (in early and mid-2013), and in Greece from slightly over $8 \%$ to slightly over $27 \%$ [5-7].

There were times the production base in Greece appeared to collapse [8], the monetary liquidity provided in the economy by banks to dry out, the unemployment rate set to reach 30\% [9], many small and medium sized firms to be squeezed out business, hopes for an export-led boost to fade, vested interests to raise the social cost of implementing reforms to prohibitive levels, foreign investors to hesitate to operate in the country [10], and so on. Eventually, the early optimistic forecasts of a mild and brief recession were revised [11], and a different policy mix of fiscal measures and growth initiatives was tried [12].

In the pages that follow we take a closer look at workforce figures, and provide a more detailed description of their development vis-à-vis the broad picture usually considered, ${ }^{1}$ and, perhaps for that reason, a less dismal point of view: a view in which a number of turning points and encouraging shifts may be detected. It goes without saying that identifying these turning points and shifts can help out other analysts to determine the events or policies that affected the said changes.

\section{Signs of Job-creation Amid the Destruction}

1 The detailed nature of employment statistics favors their use in subsectoral and subregional empirical analyses apropos the other usual measure of economic performance and comparison: the GDP. 


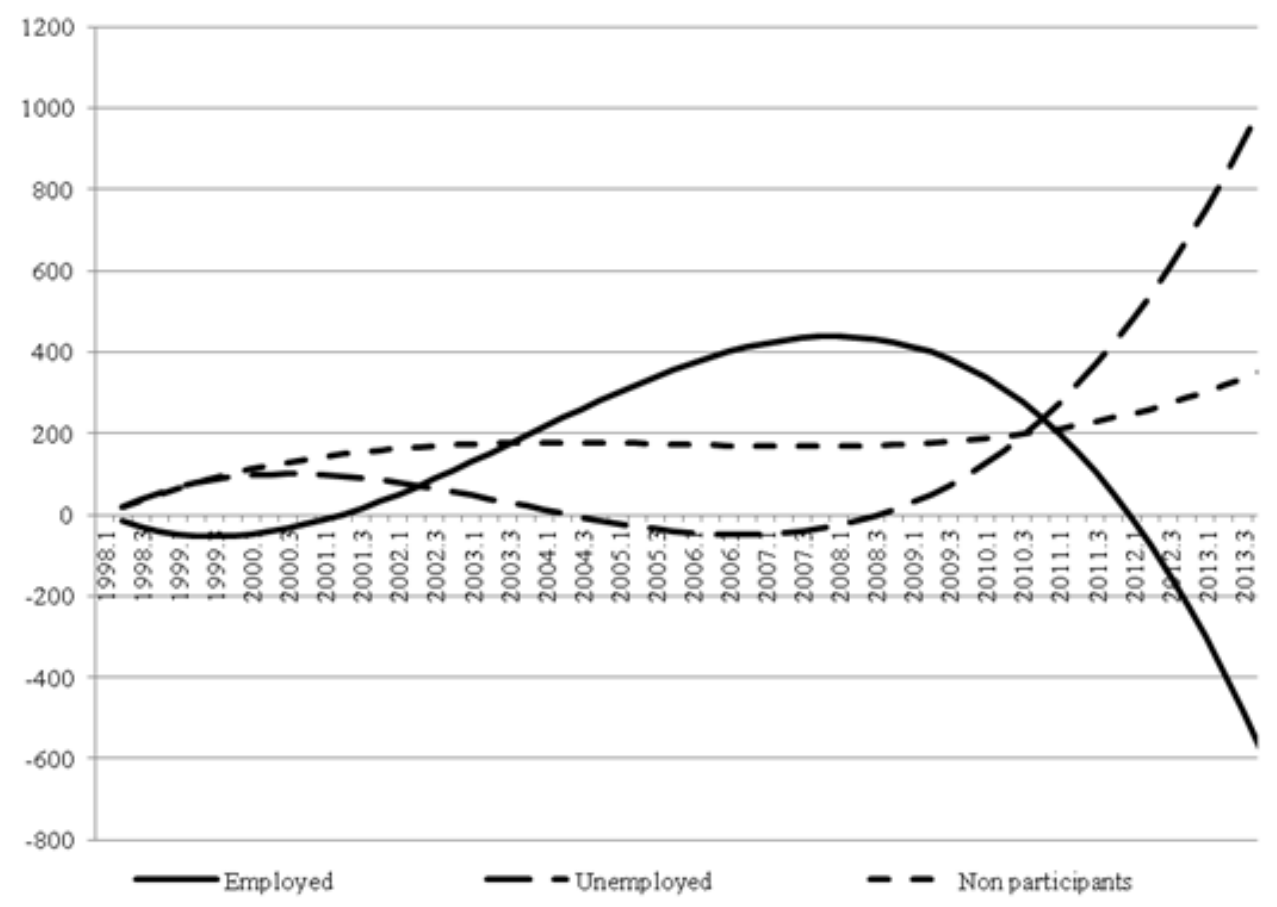

Source: ELSTAT. Own calculations.

Figure 1. The evolution of employment, unemployment and workforce non-participation figures in terms of long and medium term patterns (1988 Q1 2013 Q4)

Table 1. Released Greek LFS estimates regarding the first quarters of 2008 and 2013

\begin{tabular}{|c|c|c|c|c|c|}
\hline \multirow[b]{2}{*}{ People aged 15 years of older } & \multicolumn{2}{|c|}{2008 Q1 } & \multicolumn{2}{|c|}{2013 Q1 } & \multirow{2}{*}{$\begin{array}{c}\text { rate of change } \\
(\%)\end{array}$} \\
\hline & thousands & share (\%) & thousands & share $(\%)$ & \\
\hline Employed & 4511.6 & 48.9 & 3595.9 & 38.3 & -20.3 \\
\hline - $\quad$ Agriculture, forestry, fishing & 517.9 & 5.6 & 487.4 & 5.2 & -5.9 \\
\hline - Mining, quarrying & 17.8 & 0.2 & 10.4 & 0.1 & -41.6 \\
\hline - Manufacture & 540.6 & 5.9 & 339.4 & 3.6 & -37.2 \\
\hline - Electricity, gas, steam, air condition supply & 37.3 & 0.4 & 29.7 & 0.3 & -20.4 \\
\hline - Water supply, sewerage, waste management & 28.3 & 0.3 & 20 & 0.2 & -29.3 \\
\hline - Construction & 395.4 & 4.3 & 177.6 & 1.9 & -55.1 \\
\hline - $\quad$ Trade & 815.5 & 8.8 & 650.5 & 6.9 & -20.2 \\
\hline - Transportation, storage & 288.2 & 3.1 & 183 & 1.9 & -36.5 \\
\hline - Accommodation, food service & 210.4 & 2.3 & 238.9 & 2.5 & +13.5 \\
\hline - Information, communication & 71.3 & 0.8 & 78.6 & 0.8 & +10.2 \\
\hline - Financial, insurance activities & 121.8 & 1.3 & 105.5 & 1.1 & -13.4 \\
\hline - $\quad$ Real estate & 8.6 & 0.1 & 2.6 & 0.0 & -69.8 \\
\hline - Professional, scientific, technical activities & 227.3 & 2.5 & 203.8 & 2.2 & -10.3 \\
\hline - Administrative and support activities & 76.3 & 0.8 & 59.4 & 0.6 & -22.1 \\
\hline - Public admin., defense, comp. soc. security & 375.9 & 4.1 & 336.9 & 3.6 & -10.4 \\
\hline - Education & 322.5 & 3.5 & 275.8 & 2.9 & -14.5 \\
\hline - Health, social work activities & 239.1 & 2.6 & 224.2 & 2.4 & -6.2 \\
\hline - Arts, entertainment, recreation & 55.6 & 0.6 & 44 & 0.5 & -20.9 \\
\hline - Other service activities & 89.7 & 1.0 & 73.9 & 0.8 & -17.6 \\
\hline - Activities featuring households as employers & 70.4 & 0.8 & 53.2 & 0.6 & -24.4 \\
\hline - Activities of extraterritorial organizations & 1.9 & 0.0 & 1.2 & 0.0 & -36.8 \\
\hline Unemployed & 406.5 & 4.4 & 1355.2 & 14.4 & +233.4 \\
\hline Non participants in the labor market & 4304.5 & 46.7 & 4440.6 & 47.3 & +3.2 \\
\hline Population & 9222.6 & 100.0 & 9391.7 & 100.0 & +1.8 \\
\hline
\end{tabular}


According to the Greek Statistical Authority's (ELSTAT) periodic Labor Force Surveys (LFS), between the first quarters of 2008 and 2013 (i.e., 2008 Q1 and 2013 Q1, respectively, in terms of the usual shorthand notation), the number of people in employment fell by 916 thousand $(-20.3 \%)$, while the number of unemployed and non-participants in the labor force rose by 949 thousand $(+233.4 \%)$ and 136.1 thousand $(+3.2 \%)$, respectively. See Figure 1 and Table 1.

This arithmetic is not instantly conducive to arguments of potential Schumpeterian-like creative destruction. However, there are glimpses of such a restructure taking place under the surface, esp. if the analyst turns to more disaggregated statistical levels: sectoral and sub-sectoral, regional and sub-regional or demographic.

Moving on in this direction, we note that: (a) The bulk of job losses $(88 \%)$ occurred in the sectors with the most staff: construction ( -217.8 thousand people, i.e. $23.8 \%$ of all job losses), manufacture (-201.2 thousand, i.e., 22.0\%), trade (-165.0 thousand, i.e., 18\%), transportation and storage, ( -105.2 thousand, i.e., $11.5 \%)$, education ( -46.7 thousand, i.e., 5.1\%), public administration, defense and compulsory social security ( -39.0 thousand, i.e., $4.3 \%)$, agriculture, forestry and fishing (-30.5 thousand, 3.3\%); with the largest shedding in relative terms taking place in real estate (by $69.8 \%$ ), construction $(55.1 \%)$, mining and quarrying $(41,6 \%)$, manufacture (37.2\%). (b) Employment figures grew in accommodation and food services, and information and communication by 13.5 and 10.2 thousand people, respectively.

Not only is the process not uniform, but at the regional level the trends and cyclical fluctuations (hereinafter, the long and medium term patterns) of the employment, unemployment and non-participation figures also show considerable diversity once the seasonal impact and noise components are econometrically removed. See Figure 2.

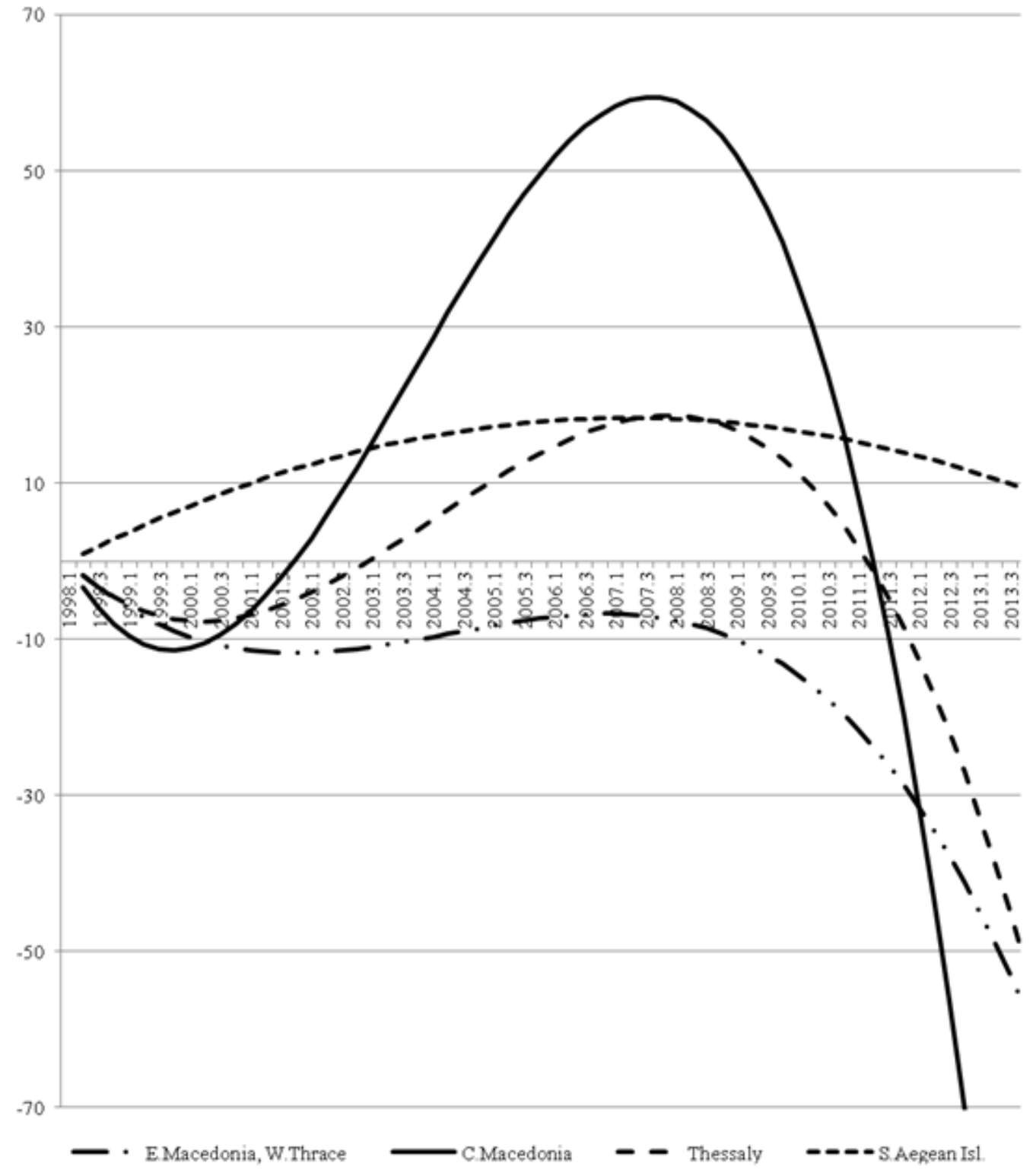

Source: See Figure 1.

Figure 2. Diverse long and medium term regional employment patterns in Greece (1988 Q1 - 2013 Q4) 


\section{Changes in Employment by Sub-sector and Region}

Firstly, we turn to the empirical examination of the regional employment figures in each of the country's 88 sub-sectors of economic activity [13] in order to identify the long and medium term time patterns, $T$, along with seasonality, $S$ (with the aim of removing it), using a close variant of the functional form described by Cameron [14] and others: ${ }^{2}$

$$
\mathrm{Y}=\sum_{i=1}^{13}\left(a_{i} \times T_{i}+\beta_{i} \times T_{i}^{2}+\gamma_{i} \times S_{j i}\right) .
$$

The left hand variable consists of ELSTAT's employment figures of people aged 15 years or older from the first quarter of 2008 to the first quarter of 2013 in each of Greece's thirteen NUTS level 2 regions (i.e., 273 observations). ${ }^{3}$ These figures are calculated from the LFS sample on the basis of weights and are by and large presumed to pertain to the whole population. In this setting $i$ denotes the regions, $j$ the quarters (in the form of categorical variables), while $\alpha, \beta$ and $\gamma$ stand for the function's coefficients. With the ratio of regressors to observations at 1:4.2 we refrain from adding more explanatory variables $[16,17]$; and in order to deal with heteroscedastic residuals we resort to regression analyses with robust standard errors [18].

The recovery of statistically significant results for both $a$ and $\beta$ at the $1 \%$ level, and the estimation of the twice differentiable function with respect to $T$, suggest the presence of a good number of upward sub-sectoral employment patterns across the country in:

- The mining of metal ores (sub-sector \#07) in eleven of the country's thirteen regions.

- The manufacture of chemicals and chemical products (\# 20) in seven regions.

- The manufacture of leather and related products (\#15), the manufacture of machinery and equipment $(\# 28)$, the supply of electricity, gas, steam and air conditioning (\#35) in six regions.

- 74 other economic activities in fewer regions. (See Table 2.)

The number is rather impressive given the circumstances and suggests there is considerable movement beneath the surface during the economic contraction. Of these cases:

- A good number occurred along a crescent-like formation stretching from Epiros (23 cases), the Ionian islands (Ion), and the Southern, Central and Eastern Peloponnese (SCEP) to Crete (21 cases), and Thessaly (20).
- A modest number occurred in Western Greece (WGre), East Macedonia and Western Thrace (EMWT), the neighboring North Aegean islands (NAeg) (17 cases), West Macedonia (WMac) (15 cases), Central Greece and Euboea (CGE), and the neighboring South Aegean islands (SAeg) (14 cases).

- A small number took place in the heavily populated regions of Attiki (10 cases) and Central Macedonia (CMac) (13 cases), where the major urban centers of Athens and Thessaloniki are located.

- More than half (51\%) came about in a relatively short period of time running from the third quarter of 2010 (i.e., right after the signing of the MOU and the deepening of the recession in Greece) to the second quarter of 2011 (at which time the rest of the Euro-zone slipped into a second recession), and one fourth $(25 \%)$ in the four-quarter period following that.

\section{Changes in Non-participation in the Workforce by Region}

In carrying out similar regressions for the unemployed and non-participating male and female populations, reversals in the general pattern are detected in:

- Attiki in the form of a decline in non-participating females figures from the fourth quarter of 2008 onwards.

- Western Greece and Epirus in the form of declining male non-participation figures from the first quarter of 2009 onwards in both regions, and declining female non-participating figures from the fourth quarter of 2009 in the former region, and from the first quarter of 2010 onwards in the latter region.

- Western Macedonia, Crete and the North Aegean islands in the form of declining female non-participating figures from the third and fourth quarters of 2009, and from the fourth quarter of 2010 , respectively.

So, despite the overall increase in non-participation figures (which may be linked to worker discouragement), from the analysis undertaken at the regional level it seems that the contraction in economic activity may have prompted segments of the population in parts of the country to join the workforce (presumably to augment household income).

\footnotetext{
2 The use of more sophisticated tools is not without problems [15].

3 The Nomenclature des Unités Territoriales Statistiques (NUTS) is the five-tier hierarchical structure used in the EU to standardize territorial units. In Greece, the administrative regions (periferies) correspond to NUTS level 2 sized-districts; prefectures (nomoi) correspond to NUTS level 3 sized-districts; and municipalities (demoi, koinotites) to upper level Local Administrative Units (LAU 1, occasionally termed NUTS level 4).
} 
Table 2. Upward employment trends across sub-sectors of economic activity and regions in Greece as per the statistical significant results (2008 Q1 - 2013 Q1)

\begin{tabular}{|c|c|c|c|c|c|c|c|c|c|c|c|c|c|}
\hline \multirow{2}{*}{ Sub-sectors (divisions) of economic activity (79 out of 88 subsectors) } & \multicolumn{13}{|c|}{ Territorial units and estimated commencement times of upward employment trends } \\
\hline & EMWT & CMac & WMac & Epiros & Thessaly & WGre & CGE & Attiki & SCEP & Crete & SAeg & NAeg & Ion \\
\hline Forestry, logging $(\# 02)$ & 2010 Q3 & & & & & & & & & & & & \\
\hline Fishing, aquaculture (\#03) & & & & 2010 Q1 & 2010 Q1 & 2008 Q1 & $2011 \mathrm{Q} 2$ & & & & 2011 Q4 & & \\
\hline Mining of coal and lignite (\#05) & & 2009 Q4 & & & & & & & & 2010 Q1 & & & \\
\hline Mining of metal ores (\#07) & 2010 Q1 & & $2010 \mathrm{Q} 3$ & 2010 Q4 & 2010 Q4 & 2010 Q4 & 2011 Q2 & 2010 Q3 & 2010 Q4 & 2010 Q4 & & 2010 Q4 & $2010 \mathrm{Q} 4$ \\
\hline Other mining, quarrying (stone, sand, clay, gypsum, chalk, peat, salt) (\#08) & & & & & & & $2011 \mathrm{Q} 1$ & & 2009 Q4 & & & 2008 Q1 & \\
\hline Manufacture of food products (\#10) & 2011 Q4 & & & & & & & & & & 2010 Q3 & & \\
\hline Manufacture of beverages (\#11) & & & & & $2011 \mathrm{Q} 2$ & & & & & 2010 Q1 & & & 2010 Q2 \\
\hline Manufacture of tobacco products (\#12) & & & & & & & & & 2010 Q1 & & & & \\
\hline Manufacture of textiles (\#13) & & 2011 Q3 & & & $2012 \mathrm{Q} 1$ & & & & $2011 \mathrm{Q} 3$ & & & & 2009 Q3 \\
\hline Manufacture of wearing apparel (\#14) & & & & & & & & & 2011 Q2 & & & & \\
\hline Manufacture of leather and related products (\#15) & & & $2011 \mathrm{Q} 2$ & $2010 \mathrm{Q} 4$ & & 2010 Q4 & & & 2010 Q4 & & & 2010 Q4 & 2010 Q4 \\
\hline Manufacture of wood (excl. furniture), wood/cork/straw products (\#16) & $2011 \mathrm{Q} 3$ & & & & & & & & & & 2010 Q3 & & \\
\hline Manufacture of paper and paper products (\#17) & & & & 2009 Q4 & & & & & & & & & 2010 Q2 \\
\hline Printing and reproduction of recorded media (\#18) & $2011 \mathrm{Q} 4$ & & & $2011 \mathrm{Q} 3$ & $2011 \mathrm{Q} 1$ & & & & & 2011 Q1 & & & \\
\hline Manufacture of chemicals and chemical products ( $\# 20)$ & 2010 Q3 & & 2011 Q4 & & & 2010 Q1 & & & 2011 Q2 & & $2011 \mathrm{Q} 2$ & 2010 Q4 & 2010 Q4 \\
\hline Manufacture of basic pharmaceutical products, relevant preparations ( $\# 21$ ) & & & & & 2012 Q1 & & & & 2011 Q1 & 2011 Q3 & & 2010 Q4 & \\
\hline Manufacture of rubber and plastic products ( $\# 22)$ & & & & $2011 \mathrm{Q} 4$ & & & & & & 2010 Q4 & & $2011 \mathrm{Q} 3$ & \\
\hline Manufacture of other non-metallic mineral products ( $\# 23$ ) & & & & $2011 \mathrm{Q} 4$ & & & & & 2010 Q3 & & & & \\
\hline Manufacture of basic metals ( $\# 24$ ) & & & 2012 Q1 & $2011 \mathrm{Q} 4$ & & 2010 Q3 & & 2010 Q4 & & & & & \\
\hline Manufacture of computer, electronic and optical products (\#26) & 2012 Q2 & & & & & $2011 \mathrm{Q} 2$ & & & & & & & $2011 \mathrm{Q} 2$ \\
\hline Manufacture of electrical equipment (\#27) & & & & & $2011 \mathrm{Q} 2$ & & & & & & $2010 \mathrm{Q} 4$ & & 2010 Q4 \\
\hline Manufacture of machinery and equipment (\#28) & & & 2010 Q2 & 2011 Q3 & 2011 Q3 & & & & 2012 Q1 & 2011 Q4 & & & 2010 Q4 \\
\hline Manufacture of motor vehicles, trailers and semi-trailers (\#29) & & & & $2011 \mathrm{Q} 4$ & 2010 Q1 & & $2011 \mathrm{Q} 2$ & & & & & & \\
\hline Manufacture of other transport equipment (\#30) & & 2010 Q4 & 2011 Q2 & $2011 \mathrm{Q} 2$ & & & & & & & & 2010 Q4 & 2010 Q4 \\
\hline Manufacture of furniture (\#31) & & & & & & & & & & & & & 2010 Q1 \\
\hline Other manufacture. (jewel., musical, sport, medical/dental instr., toys etc.) (\#32) & $2011 \mathrm{Q} 1$ & & & & $2011 \mathrm{Q} 1$ & & & & 2011 Q1 & & & 2010 Q4 & \\
\hline Repair and installation of machinery and equipment (\#33) & & & & & & & & & 2011 Q2 & & & & \\
\hline
\end{tabular}


Table 2. (continued)

\begin{tabular}{|c|c|c|c|c|c|c|c|c|c|c|c|c|c|}
\hline \multirow{2}{*}{ Sub-sectors (divisions) of economic activity (79 out of 88 ) } & \multicolumn{13}{|c|}{ Territorial units and estimated commencement times of upward employment trends } \\
\hline & EMWT & CMac & WMac & Epiros & Thessaly & WGre & CGE & Attiki & SCEP & Crete & SAeg & NAeg & Ion \\
\hline Electricity, gas, steam and air conditioning supply (\#35) & & 2010 Q4 & & & & 2011B & 2011B & 2011 Q3 & & & 2009 Q4 & & 2011 Q3 \\
\hline Water collection, treatment and supply (\#36) & & & & & & 2008 Q1 & & 2012 Q1 & & $2011 \mathrm{Q} 1$ & & & \\
\hline Sewerage (\#37) & 2009 Q3 & & & & & & & & & & & & \\
\hline Waste collection, treatment and disposal activities; materials recovery (\#38) & & & & & & & $2011 \mathrm{Q} 4$ & & & & & & \\
\hline Remediation activities and other waste management services (\#39) & & 2009 Q3 & & & 2011 Q2 & & $2011 \mathrm{Q} 3$ & & & & & & \\
\hline Construction of buildings (\#41) & & & 2012 Q4 & & 2011 Q4 & & 2012 Q2 & & & & & & \\
\hline Civil engineering (\#42) & & & & 2010 Q3 & & & & & 2008 Q1 & & & & \\
\hline Wholesale, retail trade and repair of motor vehicles and motorcycles (\#45) & & & & & & & & & & 2011 Q1 & 2011 Q2 & & \\
\hline Wholesale trade, except of motor vehicles and motorcycles (\#46) & & & & & & & 2012 Q2 & & & $2011 \mathrm{Q} 4$ & & & \\
\hline Retail trade, except of motor vehicles and motorcycles (\#47) & & & & & & & & & & & & 2010 Q4 & \\
\hline Land transport and transport via pipelines (\#49) & & & 2011 Q3 & 2010 Q2 & & & & & 2013 Q1 & & & & \\
\hline Air transport (\#51) & & & 2010 Q4 & 2011 Q3 & & 2009 Q4 & & & & & & & \\
\hline Warehousing and support activities for transportation ( $\# 52)$ & $2011 \mathrm{Q} 3$ & & & & & & & & & 2010 Q1 & & & \\
\hline Postal and courier activities ( $\# 53$ ) & & 2011 Q3 & & 2010 Q3 & & & 2010 Q3 & & & & & & \\
\hline Accommodation (\#55) & & & 2011 Q2 & 2008 Q1 & & & & & 2008 Q1 & 2010 Q3 & & & $2011 \mathrm{Q} 3$ \\
\hline Food and beverage service activities ( $\# 56$ ) & & & & & & & 2010 Q4 & & & & & & \\
\hline Publishing activities (\#58) & & & & 2010 Q2 & & & & & & & & & \\
\hline Motion picture, video, TV production, sound recording etc. (\#59) & $2011 \mathrm{Q} 2$ & & & 2011 Q4 & & & & & & & & & \\
\hline Programming and broadcasting activities (\#60) & & & & & & & 2011 Q2 & & & & & & \\
\hline Telecommunications (\#61) & & & & & & 2011 Q1 & $2011 \mathrm{Q} 4$ & & & 2011 Q2 & 2008 Q1 & & \\
\hline Computer programming, consultancy and related activities (\#62) & & 2011 Q1 & & 2009 Q4 & 2008 Q1 & & & & 2010 Q4 & 2010 Q2 & & & \\
\hline Information service activities (\#63) & & & & & & 2009 Q3 & & & & 2010 Q4 & & & \\
\hline Financial service activities, except insurance and pension funding (\#64) & & & 2010 Q4 & & & & & & & 2011 Q2 & & & \\
\hline Insurance, reinsurance and pension funding, excl. comp. soc. security (\#65) & 2010 Q2 & & & & & & & 2010 Q3 & & & & $2011 \mathrm{Q} 1$ & \\
\hline Activities auxiliary to financial services and insurance activities (\#66) & & & & & & & & & & & 2010 Q4 & & \\
\hline Real estate activities (\#68) & & & & & 2012 Q1 & & & & & 2011 Q2 & 2011 Q2 & & 2010 Q4 \\
\hline Legal and accounting activities (\#69) & & & & & $2008 \mathrm{Q} 1$ & 2012 Q1 & & 2011 Q4 & & & & & \\
\hline
\end{tabular}


Table 2. (continued)

\begin{tabular}{|c|c|c|c|c|c|c|c|c|c|c|c|c|c|}
\hline \multirow{2}{*}{ Sub-sectors (divisions) of economic activity ( 79 out of 88 ) } & \multicolumn{13}{|c|}{ Territorial units and estimated commencement times of upward employment trends } \\
\hline & EMWT & CMac & WMac & Epiros & Thessaly & WGre & CGE & Attiki & SCEP & Crete & SAeg & NAeg & Ion \\
\hline Activities of head offices; management consultancy activities ( $\# 70)$ & & & & & & 2012 Q1 & & & & & & & 2011 Q3 \\
\hline Architectural and engineering activities, technical testing and analysis (\#71) & & 2012 Q1 & & & & & & & & & 2010 Q2 & 2009 Q4 & 2008 Q1 \\
\hline Scientific research and development $(\# 72)$ & & & & & 2009 Q4 & & & & & & & & \\
\hline Other professional, scientific and technical activities (\#74) & & 2011 Q3 & & & & 2008 Q1 & & & & 2010 Q4 & & & 2008 Q1 \\
\hline Veterinary activities ( $\# 75$ ) & & & 2011 Q1 & & & 2010 Q2 & & 2010 Q3 & & & & & \\
\hline Rental and leasing activities (\#77) & $2011 \mathrm{Q} 4$ & & & & & 2011 Q1 & & & 2011 Q4 & & & & 2010 Q2 \\
\hline Employment activities (\#78) & 2010 Q3 & & & & & $2011 \mathrm{Q} 4$ & & & & & & & \\
\hline Travel agency, tour operator reservation service and related activities (\#79) & & & & & & & & $2012 \mathrm{Q} 3$ & 2012 Q1 & & & & \\
\hline Security and investigation activities (\#80) & 2010 Q4 & & & 2010 Q2 & & & & & & & & 2010 Q4 & \\
\hline Services to buildings and landscape activities (\#81) & & & & & & & & & & & & 2008 Q1 & \\
\hline Office administrative, support and other business support activities (\#82) & & & & & & & & & & & & 2008 Q1 & 2011 Q2 \\
\hline Public administration and defense; compulsory social security (\#84) & & 2012 Q1 & 2011 Q2 & & & & & & 2011 Q2 & & & & \\
\hline Education (\#85) & & & & & & & & & & & 2011 Q1 & & \\
\hline Human health activities (\#86) & & & & $2011 \mathrm{Q} 1$ & 2011 Q1 & & & & 2010 Q4 & 2011 Q4 & & 2008 Q1 & \\
\hline Residential care activities (\#87) & $2011 \mathrm{Q} 2$ & & & & & & & & & & & & \\
\hline Social work activities excl. accommodation (\#88) & & & & & & & & & 2010 Q3 & & 2011 Q1 & $2011 \mathrm{Q} 4$ & 2008 Q1 \\
\hline Creative arts and entertainment activities ( $\# 90)$ & & & 2010 Q4 & 2012 Q2 & & & & 2010 Q4 & & & & & \\
\hline Libraries, archives, museums and other cultural activities (\#91) & & & & & 2010 Q3 & & & & & & & & \\
\hline Gambling and betting activities ( $\# 92$ ) & & & & & & & & 2010 Q4 & & & 2009 Q4 & & $2011 \mathrm{Q} 1$ \\
\hline Sports activities and amusement and recreation activities ( $\# 93$ ) & & 2010 Q3 & $2011 \mathrm{Q} 2$ & & & & $2012 \mathrm{Q} 2$ & & & 2011 Q1 & & 2009 Q4 & \\
\hline Activities of membership organizations ( $\# 94$ ) & 2010 Q3 & 2010 Q3 & & & & & & & & & & & \\
\hline Repair of computers and of personal and household goods (\#95) & & & & & & & & & & 2010 Q3 & & & \\
\hline Other personal service activities ( $\# 96$ ) & & & & & 2010 Q4 & & & & & & & & \\
\hline Activities of households as employers of domestic personnel (\#97) & & & & & 2010 Q3 & & & & & & & & \\
\hline Activities of extraterritorial organizations and bodies (\#99) & & & & 2011 Q3 & & & & & & & & & \\
\hline
\end{tabular}

Source: See Figure 1 


\section{Changes in Employment by Demographic Group, Type of Work and Area}

Shifting our attention to intra-regional developments by demographic group we employ an equation similar to the previous one:

$$
\mathrm{Y}=\gamma_{1}+\alpha \mathrm{T}+\beta \mathrm{T}^{2}+\gamma_{2} \mathrm{Q} 2+\gamma_{3} \mathrm{Q} 3+\gamma_{4} \mathrm{Q} 4,
$$

with the left hand variable consisting of the 2008 Q1 - 2013 Q2 population figures of:

- the males and females in the urban, rural or intermediate (semi-urban) areas in each of the country's thirteen regions, broken down in thirteen age groups (15-19, 20-24,... 70-74, 75 years or older), i.e., 13 age groups $\times 2$ genders $\times 3$ types of areas $\times 13$ regions $=$ 1,014 combinations, ${ }^{4}$ organized in terms of

- the unemployed, those outside the workforce, and those employed in each of the 21 sectors of economic activity either as employers or as self-employed, employees or family members who assist the other three types of workers, both full time and part time (each type separately), i.e., some $2+(21 \times 4 \times 2)=170$ possible combinations -though some may not exist.

Here, too, the recovery of $a$ 's and $\beta$ 's with p-values equal to $1 \%$ or less across many of the 27,623 functions considered, and the estimation of the twice differentiable function with respect to $T$, suggest the presence of (a) a good number of upward non-participation and employment patterns (usually in full-time jobs), as well as (b) several downward unemployment patterns across the country.

Table 3 summarizes the spatial and demographic groupings in which the phenomena under item (a) are observed, and highlights those associated with rising or falling unemployment figures (indicated with light and dark grey, respectively). To help the reader understand the $f, p$, and $N$ symbols employed we offer the following example: The upward pattern(s) in the urban areas of Eastern Macedonia and Western Thrace observed in the number of males aged:

- 15-20 years old who work as full-time salaried employees in the trade industry is designated with the letter $f$ (for full-time) in the leftmost cell of the first row;

- 50-54 years old involved as full time (a) employers in accommodation and food services, arts-entertainment-recreation and the finance-insurance industry, (b) employees in manufacture and the informationcommunication industry, and (c) self-employed in agriculture-forestry-fishing and professional-scienti- fic-technical activities are designated with the letter $f$ (for full-time) in the leftmost dark gray cell of the first row;

- 50-54 years old (d) involved as part time employees in construction or (e) moving out of (i.e., not participating in) the workforce, are indicated with the letters $p$ (for part time) and $N$ (for not participating), respectively, in the leftmost dark gray cell of the first row; and so on.

The presence of many such $f$ (and $p$ ) symbols in the majority of sub-regions and demographic groups (including those in which the number of unemployed continues to increase (see the 86 lightly shaded cells)) intimates the creation of job opportunities and, in the cases of the 741 white cells (where the rise or fall in the number of unemployed is statistically indeterminate), considerable occupational mobility.

The distribution of the shaded cells suggests that by the end of the period under examination, the surge in the number of the unemployed:

- Had by and large subsided in the rural areas of Eastern Macedonia and Western Thrace, and the Southern, Central and Eastern Peloponnese.

- Continued to adversely affect: (a) Four male age groups in the urban areas of Crete, four female age groups in the urban areas of Western Macedonia, as well as in the semi-urban areas of Western Greece, and fewer male or female age groups in other parts of the country. (b) More often than not, groups of males aged 35-39 years and females aged 55-59 years in the urban parts of the country, females aged 40-44 years in the rural parts of country, and males aged 45-49 and 60-69 years in all three types of areas.

- Combined with the absence among certain segments of the population of significant expansions in any type employment (whether full or part time) irrespective of sector, is likely to adversely affect these segments' participation and inclusion in monetary activities. The said segments comprise females aged 15-19 years old in the urban areas of the Ionian islands, aged 20-24 in the semi-urban areas of the Ionian islands and the urban areas of Central Macedonia, aged 50-54 in the rural areas of the South Aegean islands, and males aged 60-64 years old in the urban areas of the South Aegean islands. 


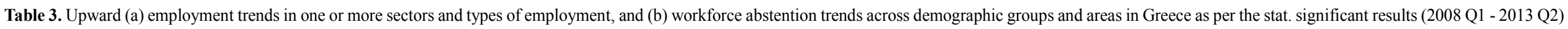

\begin{tabular}{|c|c|c|c|c|c|c|c|c|c|c|c|c|c|c|c|c|c|c|c|c|c|c|c|c|c|c|c|}
\hline \multirow[t]{2}{*}{ Region } & \multirow[t]{2}{*}{ Area } & \multicolumn{13}{|c|}{ Males (organized by age groups) } & \multicolumn{13}{|c|}{ Females (organized by age groups) } \\
\hline & & $15-19$ & $20-4$ & $25-29$ & $30-34$ & $35-39$ & $40-44$ & $45-49$ & $50-54$ & $55-59$ & 60-64 & 65-69 & $70-74$ & $75+$ & $15-19$ & $20-24$ & $25-29$ & $30-34$ & $35-39$ & $40-44$ & $45-49$ & $50-54$ & $55-59$ & $60-64$ & $65-69$ & $70-74$ & $75+$ \\
\hline & & 123 & 123 & 123 & 123 & 123 & 123 & 123 & 123 & 123 & 123 & 123 & 123 & 123 & 123 & 123 & 123 & 123 & 123 & 123 & 123 & 123 & 123 & 123 & 123 & 123 & 123 \\
\hline \multirow[t]{3}{*}{ EMWT } & urban & $\mathrm{f}$ & $\mathrm{fp}$ & $\mathrm{fp}$ & $\mathrm{fp}$ & $\mathrm{fpN}$ & $\mathrm{f}$ & $\mathrm{f}$ & $\mathrm{fpN}$ & $\mathrm{f}$ & $\mathrm{f}$ & $\mathrm{fp}$ & & & $\mathrm{f}$ & $\mathrm{fp}$ & $\mathrm{fp}$ & $\mathrm{fp}$ & $\mathrm{fp}$ & $\mathrm{fp}$ & $\mathrm{fp}$ & $\mathrm{f}$ & $\mathrm{fp}$ & $\mathrm{f}$ & & & \\
\hline & interm. & $\overline{\mathrm{fN}}$ & $\mathrm{f}$ & $\mathrm{fpN}$ & $\mathrm{f}$ & $\mathrm{fp}$ & $\mathrm{f}$ & $\mathrm{f}$ & $\mathrm{f}$ & $\mathrm{f}$ & $\bar{f}$ & $\mathrm{fp}$ & $\mathrm{f}$ & & & $\mathrm{fp}$ & $\mathrm{f}$ & $\mathrm{f}$ & $\mathrm{fp}$ & $\mathrm{fpN}$ & $\mathrm{f}$ & $\mathrm{fp}$ & & $\mathrm{f}$ & & $\mathrm{N}$ & \\
\hline & rural & $\mathrm{fp}$ & $\mathrm{fp}$ & $\mathrm{f}$ & $\mathrm{fp}$ & $\mathrm{fp}$ & $\mathrm{f}$ & $\mathrm{fp}$ & $\mathrm{fp}$ & $\mathrm{p}$ & $\mathrm{f}$ & $\mathrm{fN}$ & $\mathrm{f}$ & $\mathrm{f}$ & $\mathrm{fN}$ & $\mathrm{fN}$ & & $\mathrm{f}$ & $\mathrm{fp}$ & $\mathrm{fp}$ & $\mathrm{fp}$ & $\mathrm{fp}$ & $\mathrm{f}$ & $\mathrm{fp}$ & $\mathrm{N}$ & & $\mathrm{f}$ \\
\hline \multirow[t]{3}{*}{$\mathrm{CMac}$} & urban & $\mathrm{fN}$ & $\mathrm{fp}$ & $\mathrm{fp}$ & $\mathrm{fp}$ & $\mathrm{fp}$ & $\mathrm{f}$ & $\mathrm{fp}$ & $\mathrm{fp}$ & $\mathrm{fp}$ & $\mathrm{fp}$ & $\mathrm{fp}$ & $\mathrm{fpN}$ & & $\mathrm{fN}$ & $\mathrm{fp}$ & $\mathrm{fp}$ & $\mathrm{fp}$ & $\mathrm{fp}$ & $\mathrm{fp}$ & $\mathrm{fp}$ & $\mathrm{fp}$ & $\mathrm{fp}$ & $\mathrm{fp}$ & $\mathrm{f}$ & $\mathrm{fp}$ & $\mathrm{N}$ \\
\hline & interm. & & $\mathrm{f}$ & $\mathrm{f}$ & $\mathrm{fN}$ & $\mathrm{f}$ & $\mathrm{f}$ & $\mathrm{f}$ & $\mathrm{f}$ & $\mathrm{fp}$ & $\mathrm{fpN}$ & $\mathrm{fN}$ & & $\mathrm{p}$ & $\mathrm{f}$ & $\mathrm{f}$ & $\mathrm{f}$ & $\mathrm{fp}$ & $\mathrm{fp}$ & $\mathrm{fp}$ & $\mathrm{fp}$ & $\mathrm{f}$ & $\mathrm{fp}$ & $\mathrm{f}$ & $\mathrm{f}$ & $\mathrm{f}$ & \\
\hline & rural & $\mathrm{f}$ & $\mathrm{fp}$ & $\mathrm{fp}$ & $\mathrm{f}$ & $\mathrm{fN}$ & $\mathrm{fp}$ & $\mathrm{fp}$ & $\mathrm{fN}$ & $\mathrm{f}$ & $\mathrm{f}$ & $\mathrm{fN}$ & $\mathrm{fp}$ & $\mathrm{f}$ & $\mathrm{f}$ & & $\mathrm{fp}$ & $\mathrm{fp}$ & $\mathrm{fp}$ & $\mathrm{fp}$ & $\mathrm{fp}$ & $\mathrm{fp}$ & $\mathrm{f}$ & $\mathrm{fp}$ & & $\mathrm{f}$ & $\mathrm{N}$ \\
\hline \multirow[t]{3}{*}{ WMac } & urban & $\mathrm{N}$ & $\mathrm{f}$ & $\mathrm{fp}$ & $\mathrm{fpN}$ & $\mathrm{f}$ & $\mathrm{fp}$ & $\mathrm{f}$ & $\mathrm{f}$ & $\mathrm{fp}$ & $\mathrm{f}$ & & & & & & $\mathrm{fpN}$ & $\mathrm{fp}$ & $\mathrm{f}$ & $\mathrm{fp}$ & $\mathrm{f}$ & $\mathrm{fp}$ & $\mathrm{fp}$ & $\mathrm{fp}$ & & $\mathrm{N}$ & \\
\hline & interm. & & $\mathrm{fN}$ & $\mathrm{f}$ & $\mathrm{fp}$ & $\mathrm{fN}$ & $\mathrm{fN}$ & $\mathrm{f}$ & $\mathrm{f}$ & $\mathrm{f}$ & $\mathrm{f}$ & & $\mathrm{N}$ & & $\mathrm{p}$ & $\mathrm{f}$ & $\mathrm{fN}$ & $\mathrm{f}$ & $\mathrm{fp}$ & $\mathrm{p}$ & $\mathrm{fp}$ & $\mathrm{f}$ & $\mathrm{fp}$ & & & $\mathrm{N}$ & \\
\hline & rural & $\mathrm{fp}$ & $\mathrm{f}$ & $\mathrm{fp}$ & $\mathrm{fp}$ & $\mathrm{fp}$ & $\mathrm{f}$ & $\mathrm{f}$ & $\mathrm{fp}$ & $\mathrm{fpN}$ & $\mathrm{fp}$ & $\mathrm{fN}$ & $\mathrm{f}$ & $\mathrm{N}$ & $\mathrm{N}$ & $\mathrm{f}$ & $\mathrm{fp}$ & $\mathrm{p}$ & $\mathrm{fp}$ & $\mathrm{f}$ & $\mathrm{fp}$ & $\mathrm{fp}$ & $\mathrm{fp}$ & $\mathrm{fN}$ & $\mathrm{p}$ & $\mathrm{N}$ & \\
\hline \multirow[t]{3}{*}{ Epiros } & urban & $\mathrm{f}$ & $\mathrm{f}$ & $\mathrm{fp}$ & $\mathrm{f}$ & $\mathrm{f}$ & $\mathrm{f}$ & $\mathrm{f}$ & $\mathrm{fp}$ & $\mathrm{f}$ & $\mathrm{f}$ & $\mathrm{fpN}$ & $\mathrm{N}$ & $\mathrm{p}$ & $\mathrm{fN}$ & $\mathrm{fN}$ & $\mathrm{fp}$ & $\mathrm{fp}$ & $\mathrm{f}$ & $\mathrm{fp}$ & $\mathrm{f}$ & $\mathrm{fp}$ & $\mathrm{fpN}$ & $\mathrm{fp}$ & & $\mathrm{N}$ & \\
\hline & interm. & & $\mathrm{fN}$ & $\mathrm{f}$ & $\mathrm{fp}$ & $\mathrm{f}$ & $\mathrm{fN}$ & $\mathrm{fN}$ & $\mathrm{fp}$ & $\mathrm{f}$ & $\mathrm{f}$ & & $\mathrm{f}$ & $\mathrm{N}$ & & $\mathrm{p}$ & $\mathrm{f}$ & $\mathrm{fpN}$ & $\mathrm{f}$ & $\mathrm{f}$ & $\mathrm{f}$ & $\mathrm{fp}$ & $\mathrm{f}$ & & & $\mathrm{N}$ & \\
\hline & rural & $\mathrm{f}$ & $\mathrm{f}$ & $\mathrm{f}$ & $\mathrm{fp}$ & $\mathrm{fp}$ & $\mathrm{fp}$ & $\mathrm{fp}$ & $\mathrm{fp}$ & $\mathrm{fp}$ & $\mathrm{fp}$ & $\mathrm{f}$ & $\mathrm{f}$ & & $\mathrm{f}$ & $\mathrm{fN}$ & $\mathrm{fp}$ & $\mathrm{fp}$ & $\mathrm{fp}$ & $\mathrm{f}$ & $\mathrm{fp}$ & $\mathrm{fp}$ & $\mathrm{f}$ & $\mathrm{f}$ & & & $\mathrm{p}$ \\
\hline \multirow[t]{3}{*}{ Thessaly } & urban & $\mathrm{f}$ & $\mathrm{fN}$ & $\mathrm{f}$ & $\mathrm{f}$ & $\mathrm{f}$ & $\mathrm{fN}$ & $\mathrm{fp}$ & $\mathrm{fp}$ & $\mathrm{f}$ & $\mathrm{fN}$ & $\mathrm{fp}$ & $\mathrm{p}$ & $\mathrm{f}$ & $\mathrm{p}$ & $\mathrm{fp}$ & $\mathrm{fp}$ & $\mathrm{fp}$ & $\mathrm{fp}$ & $\mathrm{fp}$ & $\mathrm{fpN}$ & $\mathrm{fp}$ & $\mathrm{f}$ & $\mathrm{f}$ & $\mathrm{f}$ & $\mathrm{f}$ & $\mathrm{N}$ \\
\hline & interm. & $\mathrm{N}$ & $\mathrm{f}$ & $\mathrm{f}$ & $\mathrm{fp}$ & $\mathrm{fp}$ & $\mathrm{fN}$ & $\mathrm{fp}$ & $\mathrm{f}$ & $\mathrm{fpN}$ & $\mathrm{fN}$ & $\mathrm{f}$ & $\mathrm{f}$ & $\mathrm{p}$ & & & $\mathrm{fp}$ & $\mathrm{fp}$ & $\mathrm{f}$ & $\mathrm{fp}$ & $\mathrm{f}$ & $\mathrm{f}$ & $\mathrm{fpN}$ & & $\mathrm{fN}$ & & $\mathrm{N}$ \\
\hline & rural & & $\mathrm{f}$ & $\mathrm{fp}$ & $\mathrm{fp}$ & $\mathrm{fp}$ & $\mathrm{fp}$ & & $\mathrm{fp}$ & $\mathrm{fp}$ & $\mathrm{fp}$ & $\mathrm{f}$ & $\mathrm{fp}$ & $\mathrm{f}$ & & $\mathrm{fp}$ & $\mathrm{fp}$ & $\mathrm{fp}$ & $\mathrm{fN}$ & $\mathrm{fp}$ & $\mathrm{f}$ & $\mathrm{fp}$ & $\mathrm{fp}$ & $\mathrm{fp}$ & $\mathrm{fpN}$ & $\mathrm{f}$ & $f$ \\
\hline \multirow[t]{3}{*}{ WGre } & urban & $\mathrm{f}$ & $\mathrm{fN}$ & $\mathrm{fp}$ & $\mathrm{fpN}$ & $\mathrm{fp}$ & fpN & $\mathrm{f}$ & $\mathrm{f}$ & $\mathrm{f}$ & $\mathrm{fp}$ & $\mathrm{f}$ & $\mathrm{p}$ & $\mathrm{N}$ & $\mathrm{N}$ & $\mathrm{f}$ & $\mathrm{fp}$ & $\mathrm{fp}$ & $\mathrm{f}$ & $\mathrm{fp}$ & $\mathrm{fpN}$ & $\mathrm{fp}$ & $\mathrm{f}$ & $\mathrm{fp}$ & $\mathrm{f}$ & $\mathrm{fN}$ & \\
\hline & interm. & & $\mathrm{f}$ & $\mathrm{f}$ & $\mathrm{fN}$ & & $\mathrm{fp}$ & $\mathrm{fN}$ & $\mathrm{f}$ & $\mathrm{f}$ & $\mathrm{f}$ & $\mathrm{f}$ & & & $\mathrm{f}$ & $\mathrm{f}$ & $\mathrm{f}$ & $\mathrm{fp}$ & $\mathrm{f}$ & $\mathrm{fp}$ & $\mathrm{f}$ & $\mathrm{f}$ & $\mathrm{fp}$ & $\mathrm{f}$ & $\mathrm{p}$ & $\mathrm{N}$ & \\
\hline & rural & $\mathrm{fp}$ & $\mathrm{p}$ & $\mathrm{fp}$ & $\mathrm{fpN}$ & $\mathrm{f}$ & $\mathrm{fpN}$ & $\mathrm{fN}$ & $\mathrm{fp}$ & $\mathrm{f}$ & $\mathrm{fp}$ & $\mathrm{f}$ & $\mathrm{f}$ & & $\mathrm{f}$ & $\mathrm{f}$ & $\mathrm{fp}$ & $\mathrm{f}$ & $\mathrm{f}$ & $\mathrm{fp}$ & $\mathrm{fpN}$ & $\mathrm{f}$ & $\mathrm{fp}$ & $\mathrm{f}$ & & $\mathrm{f}$ & \\
\hline \multirow[t]{3}{*}{ CGE } & urban & $\mathrm{f}$ & $\mathrm{f}$ & $\mathrm{f}$ & $\mathrm{f}$ & $\mathrm{fp}$ & $\mathrm{f}$ & $\mathrm{f}$ & $\mathrm{f}$ & $\mathrm{f}$ & $\mathrm{f}$ & $\mathrm{f}$ & & & $\mathrm{fN}$ & $\mathrm{fpN}$ & $\mathrm{fp}$ & $\mathrm{fp}$ & $\mathrm{fp}$ & $\mathrm{fp}$ & $\mathrm{f}$ & $\mathrm{fp}$ & $\mathrm{fp}$ & $\mathrm{f}$ & & & \\
\hline & interm. & $\mathrm{fpN}$ & $\mathrm{fp}$ & $\mathrm{f}$ & $\mathrm{fN}$ & $\mathrm{f}$ & $\mathrm{fp}$ & $\mathrm{f}$ & $\mathrm{f}$ & $\mathrm{fp}$ & $\mathrm{f}$ & & $\mathrm{f}$ & & $\mathrm{f}$ & $\mathrm{fp}$ & $\mathrm{fp}$ & $\mathrm{fp}$ & $\mathrm{fp}$ & $\mathrm{fp}$ & $\mathrm{f}$ & $\mathrm{fp}$ & $\mathrm{f}$ & $\mathrm{fp}$ & & & \\
\hline & rural & $\mathrm{p}$ & $\mathrm{fp}$ & $\mathrm{f}$ & $\mathrm{fN}$ & $\mathrm{fN}$ & $\mathrm{fp}$ & $\mathrm{f}$ & $\mathrm{fp}$ & $\mathrm{f}$ & $\mathrm{f}$ & $\mathrm{fp}$ & $\mathrm{fp}$ & $\mathrm{p}$ & & $\mathrm{fN}$ & $\mathrm{f}$ & $\mathrm{fp}$ & $\mathrm{f}$ & $\mathrm{fp}$ & $\mathrm{fp}$ & $\mathrm{fpN}$ & $\mathrm{fp}$ & $\mathrm{p}$ & $\mathrm{N}$ & & $\mathrm{f}$ \\
\hline \multirow[t]{3}{*}{ Attiki } & urban & $\mathrm{fp}$ & $\mathrm{fp}$ & $\mathrm{fp}$ & $\mathrm{fp}$ & $\mathrm{fp}$ & $\mathrm{fp}$ & $\mathrm{f}$ & $\mathrm{f}$ & $\mathrm{fp}$ & $\mathrm{fp}$ & $\mathrm{fp}$ & $\mathrm{fp}$ & $\mathrm{fpN}$ & $\mathrm{fp}$ & $\mathrm{fp}$ & $\mathrm{fp}$ & $\mathrm{fp}$ & $\mathrm{fpN}$ & $\mathrm{fpN}$ & $\mathrm{fp}$ & $\mathrm{fp}$ & $\mathrm{f}$ & $\mathrm{f}$ & $\mathrm{f}$ & $\mathrm{fpN}$ & $\mathrm{fN}$ \\
\hline & interm. & $\mathrm{fp}$ & $\mathrm{f}$ & $\mathrm{fp}$ & $\mathrm{f}$ & $\mathrm{f}$ & $\mathrm{f}$ & $\mathrm{f}$ & $\mathrm{fp}$ & $\mathrm{f}$ & $\mathrm{f}$ & $\mathrm{f}$ & $\mathrm{fp}$ & & & $\mathrm{fp}$ & $\mathrm{fp}$ & $\mathrm{fp}$ & $\mathrm{f}$ & $\mathrm{fp}$ & $\mathrm{fp}$ & $\mathrm{fp}$ & $\mathrm{fp}$ & $\mathrm{fpN}$ & $\mathrm{fp}$ & & \\
\hline & rural & & & & $\mathrm{f}$ & $\mathrm{f}$ & $\mathrm{f}$ & $\mathrm{f}$ & $\mathrm{f}$ & $\mathrm{fN}$ & $\mathrm{f}$ & $\mathrm{f}$ & & $\mathrm{p}$ & $\mathrm{p}$ & $\mathrm{f}$ & $\mathrm{fp}$ & $\mathrm{f}$ & $\mathrm{fpN}$ & $\mathrm{f}$ & $f$ & $\mathrm{f}$ & & & $\mathrm{f}$ & & \\
\hline \multirow[t]{3}{*}{ SCEP } & urban & $\mathrm{f}$ & $\mathrm{fp}$ & $\mathrm{fp}$ & $\mathrm{fp}$ & $\mathrm{fN}$ & $\mathrm{fp}$ & $\mathrm{fp}$ & $\mathrm{f}$ & $\mathrm{fp}$ & $\mathrm{fp}$ & $\mathrm{f}$ & $\mathrm{f}$ & $\mathrm{f}$ & $\mathrm{p}$ & $\mathrm{fpN}$ & $\mathrm{fN}$ & $\mathrm{fpN}$ & $\mathrm{fp}$ & $\mathrm{fp}$ & $\mathrm{fp}$ & $\mathrm{f}$ & $\mathrm{fp}$ & $\mathrm{fp}$ & $\mathrm{f}$ & & \\
\hline & interm. & $\mathrm{N}$ & $\mathrm{N}$ & $\mathrm{f}$ & $\mathrm{f}$ & $\mathrm{f}$ & $\mathrm{f}$ & $\mathrm{fpN}$ & $\mathrm{fp}$ & $\mathrm{fp}$ & $\mathrm{fp}$ & $\mathrm{fp}$ & $\mathrm{f}$ & $\mathrm{f}$ & & $\mathrm{p}$ & $\mathrm{fp}$ & $\mathrm{p}$ & $\mathrm{fp}$ & $\mathrm{fp}$ & $\mathrm{f}$ & $\mathrm{f}$ & $\mathrm{fp}$ & $\mathrm{fp}$ & $\mathrm{N}$ & & \\
\hline & rural & & $\mathrm{fp}$ & $\mathrm{f}$ & $\mathrm{fp}$ & $\mathrm{f}$ & $\mathrm{fp}$ & $\mathrm{fN}$ & $\mathrm{fp}$ & $\mathrm{f}$ & $\mathrm{fp}$ & $\mathrm{fp}$ & $\mathrm{fp}$ & $\mathrm{fp}$ & & & $\mathrm{f}$ & $\mathrm{fp}$ & $\mathrm{f}$ & $\mathrm{fpN}$ & $\mathrm{fp}$ & $\mathrm{fpN}$ & $\mathrm{f}$ & $\mathrm{f}$ & $\mathrm{fp}$ & $\mathrm{p}$ & $\mathrm{p}$ \\
\hline
\end{tabular}


Table 3. (continued)

\begin{tabular}{|c|c|c|c|c|c|c|c|c|c|c|c|c|c|c|c|c|c|c|c|c|c|c|c|c|c|c|c|}
\hline \multirow[t]{2}{*}{ Region } & \multirow[t]{2}{*}{ Area } & \multicolumn{13}{|c|}{ Males (organized by age groups) } & \multicolumn{13}{|c|}{ Females (organized by age groups) } \\
\hline & & $15-19$ & $20-4$ & $25-29$ & $30-34$ & $35-39$ & $40-44$ & $45-49$ & $50-54$ & $55-59$ & $60-64$ & $65-69$ & $70-74$ & $75+$ & $15-19$ & $20-24$ & $25-29$ & $30-34$ & $35-39$ & $40-44$ & $45-49$ & $50-54$ & $55-59$ & $60-64$ & $65-69$ & $70-74$ & $75+$ \\
\hline & & 123 & 123 & 123 & 123 & 123 & 123 & 123 & 123 & 123 & 123 & 123 & 123 & 123 & 123 & 123 & 123 & 123 & 123 & 123 & 123 & 123 & 123 & 123 & 123 & 123 & 123 \\
\hline \multirow[t]{3}{*}{ Crete } & urban & $\mathrm{f}$ & $\mathrm{fpN}$ & $\mathrm{fp}$ & $\mathrm{fpN}$ & $\mathrm{fp}$ & $\mathrm{fp}$ & $\mathrm{fp}$ & $\mathrm{fp}$ & $\mathrm{f}$ & $\mathrm{fp}$ & $\mathrm{fp}$ & $\mathrm{fp}$ & & $\mathrm{pN}$ & $\mathrm{f}$ & $\mathrm{fN}$ & $\mathrm{fp}$ & $\mathrm{fp}$ & $\mathrm{fp}$ & $\mathrm{fpN}$ & $\mathrm{fp}$ & $\mathrm{fpN}$ & $\mathrm{fp}$ & $\mathrm{f}$ & $\mathrm{p}$ & \\
\hline & interm. & $\mathrm{f}$ & $\mathrm{fN}$ & $\mathrm{f}$ & $\mathrm{f}$ & $\mathrm{f}$ & $\mathrm{f}$ & $\mathrm{f}$ & $\mathrm{f}$ & $\mathrm{fp}$ & $\mathrm{fp}$ & $\mathrm{f}$ & $\mathrm{fN}$ & & $\mathrm{fN}$ & fp & $\mathrm{fp}$ & $\mathrm{fp}$ & $\mathrm{fp}$ & $\mathrm{fp}$ & $\mathrm{fp}$ & $\mathrm{fpN}$ & $\mathrm{f}$ & $\mathrm{fp}$ & & & $\mathrm{N}$ \\
\hline & rural & $\mathrm{f}$ & $\mathrm{fpN}$ & $\mathrm{f}$ & $\mathrm{f}$ & $\mathrm{fN}$ & $\mathrm{fp}$ & $\mathrm{f}$ & $\mathrm{f}$ & $\mathrm{f}$ & $\mathrm{fp}$ & $\mathrm{f}$ & $\mathrm{fp}$ & $\mathrm{f}$ & & $\mathrm{f}$ & $\mathrm{fpN}$ & $\mathrm{fp}$ & $\mathrm{fp}$ & $\mathrm{fp}$ & $\mathrm{fpN}$ & $\mathrm{f}$ & $\mathrm{f}$ & $\mathrm{fp}$ & $\mathrm{f}$ & $\mathrm{f}$ & \\
\hline \multirow[t]{3}{*}{ SAeg } & urban & & $\mathrm{f}$ & $\mathrm{f}$ & $\mathrm{fp}$ & $\mathrm{f}$ & $\mathrm{fpN}$ & $\mathrm{f}$ & $\mathrm{fp}$ & $\mathrm{f}$ & & $\mathrm{f}$ & $\mathrm{f}$ & & & & $\mathrm{f}$ & $\mathrm{fpN}$ & $\mathrm{fp}$ & $\mathrm{f}$ & $\mathrm{f}$ & $\mathrm{f}$ & $\mathrm{f}$ & $\mathrm{f}$ & $\mathrm{f}$ & & \\
\hline & interm. & & $\mathrm{f}$ & $\mathrm{f}$ & $\mathrm{f}$ & $\mathrm{f}$ & $\mathrm{f}$ & $\mathrm{f}$ & $\mathrm{f}$ & f & f & $\mathrm{f}$ & & & & & $\mathrm{f}$ & $\mathrm{fp}$ & $\mathrm{p}$ & $\mathrm{fp}$ & $\mathrm{f}$ & $\mathrm{fp}$ & $\mathrm{f}$ & $\mathrm{f}$ & $\mathrm{N}$ & & \\
\hline & rural & $\mathrm{f}$ & $\mathrm{f}$ & $\mathrm{f}$ & & $\mathrm{f}$ & $\mathrm{f}$ & $\mathrm{f}$ & $\mathrm{fp}$ & $\mathrm{f}$ & $\mathrm{fN}$ & & $\mathrm{f}$ & & $\mathrm{N}$ & & $\mathrm{fp}$ & $\mathrm{f}$ & $\mathrm{fp}$ & $\mathrm{fpN}$ & $\mathrm{f}$ & & $\mathrm{fp}$ & $\mathrm{f}$ & $\mathrm{f}$ & & $\mathrm{f}$ \\
\hline \multirow[t]{3}{*}{ NAeg } & urban & & $\mathrm{fp}$ & $\mathrm{f}$ & $\mathrm{f}$ & $\mathrm{f}$ & $\mathrm{fN}$ & $\mathrm{fN}$ & $\mathrm{fp}$ & $\mathrm{fp}$ & $\mathrm{f}$ & & & & & $\mathrm{f}$ & $\mathrm{p}$ & $\mathrm{f}$ & $\mathrm{fN}$ & $\mathrm{f}$ & $\mathrm{f}$ & $\mathrm{p}$ & $\mathrm{f}$ & $\mathrm{f}$ & $\mathrm{p}$ & $\mathrm{N}$ & \\
\hline & interm. & $\mathrm{N}$ & $\mathrm{f}$ & $\mathrm{f}$ & $\mathrm{f}$ & $\mathrm{f}$ & $\mathrm{f}$ & $\mathrm{f}$ & $\mathrm{fN}$ & $\mathrm{f}$ & $\mathrm{f}$ & & & & & & $\mathrm{f}$ & $\mathrm{f}$ & $\mathrm{fp}$ & $\mathrm{f}$ & $\mathrm{f}$ & & & $\mathrm{f}$ & $\mathrm{p}$ & $\mathrm{N}$ & \\
\hline & rural & & $\mathrm{fpN}$ & $\mathrm{f}$ & $\mathrm{f}$ & $\mathrm{f}$ & $\mathrm{f}$ & $\mathrm{f}$ & $\mathrm{f}$ & $\mathrm{f}$ & $\mathrm{f}$ & $\mathrm{f}$ & $\mathrm{f}$ & $\mathrm{N}$ & $\mathrm{f}$ & $\mathrm{f}$ & $\mathrm{fp}$ & $\mathrm{fp}$ & $\mathrm{fp}$ & $\mathrm{fp}$ & $\mathrm{f}$ & $\mathrm{f}$ & $\mathrm{f}$ & $\mathrm{fp}$ & $\mathrm{fN}$ & & $\mathrm{N}$ \\
\hline \multirow[t]{3}{*}{ Ion } & urban & & $\mathrm{f}$ & $\mathrm{f}$ & $\mathrm{f}$ & $\mathrm{f}$ & $\mathrm{f}$ & $\mathrm{f}$ & $\mathrm{f}$ & $\mathrm{f}$ & $\mathrm{f}$ & & & $\mathrm{N}$ & $\mathrm{N}$ & $\mathrm{f}$ & $\mathrm{fp}$ & $\mathrm{f}$ & $\mathrm{fp}$ & $\mathrm{fp}$ & $\mathrm{fp}$ & $\mathrm{f}$ & $\mathrm{f}$ & $\mathrm{f}$ & $\mathrm{f}$ & $\mathrm{N}$ & \\
\hline & interm. & $\mathrm{N}$ & & $\mathrm{f}$ & $\mathrm{f}$ & $\mathrm{f}$ & $\mathrm{f}$ & $\mathrm{f}$ & $\mathrm{f}$ & $\mathrm{f}$ & $\mathrm{f}$ & $\mathrm{f}$ & & $\mathrm{f}$ & $\mathrm{N}$ & & $\mathrm{f}$ & $\mathrm{f}$ & $\mathrm{fp}$ & $\mathrm{f}$ & $\mathrm{f}$ & $\mathrm{N}$ & $\mathrm{f}$ & $\mathrm{p}$ & & & \\
\hline & rural & f & $\mathrm{fp}$ & $\mathrm{fp}$ & $\mathrm{f}$ & $\mathrm{fp}$ & $\mathrm{fp}$ & $\mathrm{f}$ & $\mathrm{f}$ & fp & $\mathrm{f}$ & $\mathrm{fN}$ & & $\mathrm{f}$ & & $\mathrm{fpN}$ & $\mathrm{fp}$ & $\mathrm{fp}$ & fp & $\mathrm{f}$ & $\mathrm{f}$ & $\mathrm{N}$ & $\mathrm{fp}$ & $\mathrm{fpN}$ & & & $\mathrm{N}$ \\
\hline
\end{tabular}

Key for symbols and color classification

f: full time work in at least one sector and type of employment (i.e., one of the four types of employment in one or more of the 21 sectors of economic activity)

$\mathrm{p}$ : part time work in at least one of the four types of employment in one or more sectors of economic activity

$\mathrm{N}$ : non-participation (abstention from the workforce)

light grey: rising number of unemployed

dark grey: falling number of unemployed

Source: See Figure 1. 
Table 4 lists (a) the demographic groups associated with statistically significant downward patterns in the numbers of unemployed people (62-63\% are female, often aged 20-25 and 35-39), and (b) the quarter each of these patterns' commenced: Half of these cases date to the fourth quarter of 2010 and the first quarter of 2011 (i.e., about the period mentioned at end of Chapter 3), and an additional one third to the three quarters immediately after. ${ }^{5}$ Subsequently, things slowed down. There exist slightly more cases of male groups from Eastern Macedonia and Western Thrace and the Ionian islands, as well as female groups from the Ionian islands, Crete and Western Macedonia compared to other regions; and of both genders overall in rural and urban areas compared to intermediate areas.

Table 4. Downward trends in the number of unemployed people across demographic groups and areas in Greece as per the statistical significant results (2008 Q1 - 2013 Q2)

\begin{tabular}{|c|c|c|c|c|c|c|c|}
\hline $\begin{array}{c}\text { Trend's estimated } \\
\text { commencement }\end{array}$ & Demogr. group & \multicolumn{2}{|c|}{ Region and area } & $\begin{array}{l}\text { Trend's estimated } \\
\text { commencement }\end{array}$ & Demogr. group & \multicolumn{2}{|c|}{ Region and area } \\
\hline \multirow[t]{3}{*}{2008 Q1 } & M.15-19 & Ion & urban & 2011 Q1 & M.15-19 & SCEP & rural \\
\hline & F.15-19 & Ion & interm. & & F.35-39 & WMac & rural \\
\hline & F.45-49 & Att & rural & & F.35-39 & Ion & rural \\
\hline 2010 Q3 & F.20-24 & NAeg & urban & & F.35-39 & CMAC & rural \\
\hline \multirow[t]{10}{*}{2010 Q4 } & M.65-69 & CGE & urban & & F. $40-44$ & Thessaly & rural \\
\hline & M.70-74 & Thessaly & urban & 2011 Q2 & M.30-34 & SAeg & urban \\
\hline & F.20-24 & EMWT & urban & & F. $50-54$ & Ion & interm. \\
\hline & F.20-24 & WGre & urban & & M.55-59 & Ion & rural \\
\hline & F.20-24 & Crete & urban & & F. $45-49$ & Att & rural \\
\hline & M.60-64 & EMWT & interm. & & F. $55-59$ & WMac & rural \\
\hline & M.60-64 & SAeg & interm. & 2011 Q3 & M.50-54 & EMWT & urban \\
\hline & F.20-24 & Crete & interm. & & F.60-54 & WGre & urban \\
\hline & F.20-24 & SAeg & interm. & & M.20-24 & Att & interm. \\
\hline & F.20-24 & CMAC & rural & & F.55-59 & Thessaly & interm. \\
\hline \multirow[t]{6}{*}{2011 Q1 } & F.25-29 & NAeg & urban & & M.55-59 & WMac & rural \\
\hline & F.35-39 & Ion & urban & 2011 Q4 & M.20-24 & Crete & urban \\
\hline & M.15-19 & EMWT & interm. & & F.60-54 & SCEP & urban \\
\hline & F.25-29 & $\mathrm{CMac}$ & interm. & & M.40-44 & WMac & rural \\
\hline & F.25-29 & SCEP & interm. & & F.60-54 & Epiros & rural \\
\hline & M.15-19 & Ion & rural & 2012 Q2 & F.65-69 & Crete & rural \\
\hline
\end{tabular}

Source: See Figure 1.

By listing side by side in Table 5 the cases which exhibit downward patterns in the numbers of unemployed and upward patterns in various types of sectoral employment, we note that:

- In the case of males: the downward patterns in the numbers of the unemployed are for the most part preceded by upwards patterns in the numbers of the self-employed, often in agriculture-forestry-fishing and construction (in this order).

- In the cases of females: the downward patterns in the numbers of the unemployed are for the most part preceded by upwards patterns in the numbers of employees, often in agriculture-forestry-fishing, accommodation-food service (in this order), manufacture and education.

- In both genders: the downward patterns in the numbers of the unemployed are for the most part preceded by upwards patterns primarily in full-time employment, often in agriculture-forestry-fishing, accommodation- food service (in this order), trade and construction; and to a lesser extent in part-time employment, often in agriculture-forestry-fishing.

- In urban and intermediate areas: the downward patterns in the numbers of the unemployed are for the most part preceded by upwards employment patterns primarily agriculture-forestry-fishing and accommo- dation-food service.

5 The results are consistent with those of Table 2, which describe positive changes in subsectoral employment from around the country at about the same time. 
Table 5. Downward trends in the number of unemployed people and preceding upward trends in sectoral types of employment and non participation by demographic group and area in Greece as per the statistical significant results (2008 Q1 - 2013 Q2)

\begin{tabular}{|c|c|c|c|c|}
\hline \multicolumn{4}{|c|}{$\begin{array}{l}\text { Demographic groups, regions and areas, } \\
\text { and the estimated time the downward } \\
\text { unemployment trend commenced }\end{array}$} & $\begin{array}{l}\text { Preceding rises in employment and non-participation and the estimated time of trend's upward } \\
\text { commencement (the cases of simultaneous rises are supplied in parentheses) }\end{array}$ \\
\hline \multicolumn{5}{|c|}{ Males aged } \\
\hline $20-24$ & Att & interm. & 2011 Q3 & Construction self empl. 2010 Q4. (Construction employers., Trade employees.) \\
\hline $20-24$ & Crete & urban & $2011 \mathrm{Q} 4$ & $\begin{array}{l}\text { Agric. etc. self empl. } 2008 \text { Q1, fam. memb.*2011 Q3. Construction + Trade self empl., Adm. } \\
\text { support employees*2011 Q3. (Non particip.) }\end{array}$ \\
\hline $30-34$ & SAeg & urban & 2011 Q2 & Accommod. etc. employees 2010 Q2. (Trade, self empl.) \\
\hline $40-44$ & WM & rural & 2011 Q4 & Construction employees 2010 Q3. Agric. etc. self empl. 2011 Q1. \\
\hline $50-54$ & EMWT & urban & 2011 Q3 & $\begin{array}{l}\text { Agric. etc. self empl. } 2008 \text { Q1. Arts etc. employers } 2009 \text { Q4. Non particip. } 2010 \text { Q2. } \\
\text { Professional etc. self empl. } 2010 \text { Q4. Information etc. employees. } 2011 \text { Q1. (Financial etc. } \\
\text { employers, Construction employees*.) }\end{array}$ \\
\hline $55-59$ & Ion & rural & $2011 \mathrm{Q} 2$ & $\begin{array}{l}\text { Households etc. employees, Construction employees* } 2009 \text { Q4. Trade } \\
2010 \text { Q1. Agric. etc. self empl. } 2010 \text { Q4. (Accommod. etc. self empl., } \text { Manufacturing etc. employees } \\
\text { Acoyees.) }\end{array}$ \\
\hline $55-59$ & WM & rural & $2011 \mathrm{Q} 3$ & $\begin{array}{l}\text { Agric. etc. self empl.*, Public admin. employees, Non particip. } 2011 \text { Q1. (Construction, self } \\
\text { empl.*) }\end{array}$ \\
\hline $70-74$ & Thessaly & urban & 2010 Q4 & Agric. etc. self empl.*2009 Q4. \\
\hline \multicolumn{5}{|c|}{ Females aged } \\
\hline $15-19$ & EMWT & interm. & 2011 Q1 & Agric. etc. fam. memb. 2010 Q2. \\
\hline $20-24$ & NAeg & urban & 2011 Q1 & \\
\hline $20-24$ & SAeg & interm. & 2011 Q1 & \\
\hline $20-24$ & Crete & interm. & 2011 Q1 & (Accommod. etc. employees*) \\
\hline $20-24$ & EMWT & urban & $2011 \mathrm{Q} 2$ & Health etc. employees 2010 Q4. Agric. etc. fam. memb. 2011 Q1. \\
\hline $20-24$ & $\mathrm{CM}$ & rural & 2011 Q2 & \\
\hline $20-24$ & WGre & urban & 2011 Q4 & $\begin{array}{l}\text { Accommod. etc. employees } 2010 \text { Q4. Education employees } 2011 \text { Q1, self empl.* } 2011 \text { Q3. } \\
\text { Other serv. employees*2011 Q2. Arts etc. + Information etc. + Financial etc. employees } 2011 \\
\text { Q3. }\end{array}$ \\
\hline $20-24$ & Crete & urban & 2012 Q2 & Transport etc. employees 2011 Q2. \\
\hline $25-29$ & NAeg & urban & 2010 Q4 & Professional etc., employees* 2010 Q1. \\
\hline $25-29$ & $\mathrm{CM}$ & interm. & 2011 Q3 & Public admin. employees 2011 Q1. (Accommod. etc. empl.) \\
\hline $25-29$ & SCEP & interm. & $2011 \mathrm{Q} 4$ & $\begin{array}{l}\text { Agric. etc. employees + fam. memb. } 2010 \text { Q1, self. empl* } 2010 \text { Q4. Other serv. employess } 2011 \\
\text { Q3. (Electricity etc. employees) }\end{array}$ \\
\hline $35-39$ & WM & rural & 2010 Q4 & $\begin{array}{l}\text { Accommodation etc. self empl. } 2008 \text { Q1, fam. memb.* } 2009 \text { Q4. Agric. etc. employees } 2009 \text { Q3. } \\
\text { (Trade self. empl.) }\end{array}$ \\
\hline $35-39$ & Ion & rural & $2010 \mathrm{Q} 4$ & Adm. support + Manufacturing fam. memb. 2009 Q4. Manufacturing fam. memb.*2010 Q1. \\
\hline $35-39$ & $\mathrm{CM}$ & rural & 2011 Q1 & Education employees 2009 Q4. Manufacturing employees*2010 Q1. \\
\hline $35-39$ & WM & rural & 2011 Q1 & $\begin{array}{l}\text { Agric. etc. self empl. } 2008 \text { Q1. Education employees* } 2009 \text { Q4. Accommod. etc. employers } 2010 \\
\text { Q1. }\end{array}$ \\
\hline $35-39$ & Ion & urban & 2011 Q1 & Health etc. employees 2009 Q3. Manufacturing employees, Adm. support employees* 2010 Q1. \\
\hline $40-44$ & Thessaly & rural & 2011 Q2 & (Trade self empl.) \\
\hline $45-49$ & Att & rural & 2008 Q1 & \\
\hline $50-54$ & Ion & interm. & 2010 Q4 & Non particip. 2010 Q4. \\
\hline $55-59$ & Thessaly & interm. & 2011 Q3 & $\begin{array}{l}\text { Non particip. } 2011 \text { Q1. Trade fam. memb.*2011 Q2. (Trade + Manufacturing employees, } \\
\text { Construction fam. memb.) }\end{array}$ \\
\hline $60-64$ & WGre & urban & 2010 Q4 & (Agric. etc. self empl.*) \\
\hline $60-64$ & Epiros & Rural & 2011 Q1 & $\begin{array}{l}\text { Trade self empl. } 2009 \text { Q4. Accommod. etc. fam. memb. } 2010 \text { Q1. (Agric. etc. self empl. + fam. } \\
\text { memb.) }\end{array}$ \\
\hline
\end{tabular}

* Part time

Note: The cases in which the number of unemployed declined since 2008 Q1 are excluded.

Source: See Figure 1. 


\section{Conclusions and Remarks}

The article explores the quarterly Greek LFS estimates via linear econometric regressions with robust standard errors. The aim is to isolate seasonal effects and examine the long and medium term employment, unemployment and nonparticipation patterns by demographic group and sub-region, and the sub-sectoral employment figures by region, from early 2008 to early and mid-2013.

It identifies spatial units, segments of the population, sectors and sub-sectors which diverge from the rest by exhibiting statistically significant reversals in the recessionary pattern, such as:

- Upward employment in (a) the mining of metal ores in eleven out of the country's 13 regions, (b) the manufacture of chemicals and chemical products in seven regions, and (c) 77 other economic activities (out of the economy's 88) in fewer regions. Of these cases (i) nearly half occurred along a crescent-like formation stretching from Thessaly and Epiros to the Ionian islands, the southern, central and eastern parts of the Peloponnese, and Crete; and (ii) more than half occurred in a relatively brief period of time shortly after the signing of the MOU with the EC, ECB and IMF.

- Downward patterns in the number of unemployed people across 40 demographic groups, mostly in rural and urban (rather than in intermediate) parts of the country. Six tenths of these groups are female, and about half date to a short period of time after the signing of the MOU. For the most part these developments are preceded by upwards patterns in full-time employment, often in agriculture-forestry-fishing and accommodation -food service.

- Declining non-participation among females in the regions of Attiki, Western Macedonia, Crete, and males and females in Western Greece and Epiros, prior to the MOU, and among females in the North Aegean six months after that.

The positive developments in the mining of metal ores, the manufacture of chemicals and chemical products, and the other sub-sectors in different regions, along with the opportunities that agriculture-forestry-fishing and accommodation-food services seem to provide to the unemployed in certain demographic groups and parts of the country, reveal considerable movement (adaptation) below the surface that should not to be overlooked. However, to the extent they were triggered in a brief period time after the signing of MOU, and did not spark off similar developments in other areas of the economy, they may be insufficient to instantly stem the tide. For some reason the conditions in other parts of the country or segments of the economy were not ripe or people's entrepreneurial spirit and/or skills were not at levels that might yield similar responses. The question of how the overall environment may be warmed up and become more conducive or the skills and spirit transplanted is imperative to be answered sooner rather than later.

Overall, the findings bring to light evidence of considerable heterogeneity in workforce transformation during the recession, which, in turn, strengthens the argument for more detailed and advanced spatial, sectoral or other studies (incl. field surveys and quantitative/qualitative work on specific parts of the economy identified/discovered via econometrics) in order for policy-makers to:

- obtain a better understanding of the underlying causes of these divergences and the operation of the country's economies, and

- engage in well-targeted interventions in order to stimulate recovery and growth across Greece.

In essence, the article suggests that (a) the country's economic development plans may benefit from spatially, sector- and sub-sector oriented, as well as demographically targeted policy interventions, and (b) empirical analyses can be used to identify crucial spatial, sectoral, demographic or other micro-areas in need of development policies.

\section{Acknowledgements and Endnote}

The article was written in the winter of 2013-14, and benefited from comments made by participants at the $5^{\text {th }}$ International Ioannina Meeting on Applied Economics and Finance and the $13^{\text {th }}$ Annual Conference of the European Economics and Finance Society in the summer of 2014. According to LFS statistics released shortly prior to the article's publication, by 2015 Q1 employment was up in 13 sectors (out of the economy's 21) and overall vis-à-vis 2013 Q1. However, in 2015 Q2 a new government introduced capital controls. The usual disclaimer applies.

\section{REFERENCES}

[1] ECB. The Eurozone's M1 quarterly data. Accessed via the sdw.ecb.europa.eu portal in May 2014.

[2] Eurostat. Flash estimate for the fourth quarter of 2013. Release dated February 14. Luxembourg: Eurostat Press Office, 2014.

[3] A. Petralias, S. Petros and P. Prodromídis. "Greece in recession: Economic predictions, mispredictions, forecast suggestions and policy recommendations." Cyprus Economic Policy Review, 7.2: 53-80, 2013.

[4] ELSTAT. Press Release: Quarterly national accounts. Dated May 15. Piraeus: Hellenic Statistical Authority, 2014.

[5] Eurostat. November 2013 Euro area unemployment rate at 12.1\%. Release dated January 18. Luxembourg: Eurostat Press Office, 2014.

[6] ELSTAT. Press Release: Labour Force Survey $1^{\text {st }}$ Quarter 2008. Dated June 19. Piraeus: Hellenic Statistical Authority, 2008.

[7] ELSTAT. Press Release: Labour Force Survey $2^{\text {nd }}$ Quarter 
2013. Dated September 19. Piraeus: Hellenic Statistical Authority, 2013.

[8] C. Alexiou. "'When the Bough Breaks' Making Sense of the Greek Economic 'Waterloo'." International Journal of Economics and Financial Issues, 1.3: 123-132, 2011.

[9] M. Hambaki. "Impact of the Sovereign Debt Crisis on the Greek Economy." Economic and Financial Review, 19.3: 129-147, 2012.

[10] N. Christodoulakis. "From Grexit to Growth: On Fiscal Multipliers and how to End Recession in Greece." National Institute Economic Review, 224.1: R66-R76, 2013.

[11] O. Blanchard and D. Leigh. Growth Forecast Errors and Fiscal Multipliers. IMF Working Paper, 13/1, (2013).

[12] G. Argitis and M. Nikolaidi. "The Financial Fragility and the Crisis of the Greek Government Sector." International Review of Applied Economics, 28.3: 273-291, 2014.

[13] Eurostat. NACE Rev.2 Statistical classification of economic activities in the European Community. Luxembourg: Office for Official Publications of the European Communities, 2008.

[14] S. Cameron. Econometrics. Maidenhead UK: McGraw Hill, 2005.

[15] R. Dixon and D. Shepherd. "Regional Dimensions of the Australian Business Cycle." Regional Studies, 47.2: 264-281, 2013.

[16] B.G. Tabachnick and L.S. Fidell. Using multivariate statistics. $2^{\text {nd }}$ ed. New York: Harper Collins, 1989.

[17] J..E. Bartlett II, J.W. Kotrlik, and C.C. Higgins. "Organizational Research: Determining Appropriate Sample Size in Survey Research.” Information Technology, Learning, and Performance Journal, 19.1: 43-50, 2001.

[18] R. Wilcx. Introduction to Robst Estimation and Hypothesis Testing. $3^{\text {rd }}$ ed. Waltham MA: Elsevier, 2012.

[19] ELSTAT. Résultats du Recensement de la population effectué le Avril 1951. Vol. 1. Athènes: Office National de Statistique de Grèce, 1961. 